\title{
Honeybees and their products as bioindicators for heavy metal pollution in Malta
}

\author{
Daniel Borg, Everaldo Attard* \\ a Institute of Earth Systems, L-Università ta'Malta, Msida, Malta. \\ *everaldo.attard@um.edu.mt
}

Received: November 13, 2019 / Accepted: December 12, 2019 / Published online: January 20, 2020

\begin{abstract}
In this study, honeybees, propolis, air, soil and plant samples were gathered from two contrasting sites Hal Luqa (industrial area) and L-Imgarr (agricultural area) in mainland Malta. Superficial heavy metals were extracted from the samples and tested using microwave plasma-atomic emission spectrometry in order to determine the concentrations of $\mathrm{Ag}, \mathrm{As}, \mathrm{Cd}, \mathrm{Cr}, \mathrm{Cu}, \mathrm{Pb}, \mathrm{Sn}$, $\mathrm{Zn}, \mathrm{Ni}$ and $\mathrm{Hg}$. The honeybee and propolis samples were digested using nitric acid and hydrogen peroxide and then ashed using a muffle furnace in order to prepare mineral solutions. Simultaneously the air samplers, soil and plant samples were washed using de-ionised water in order to extract the heavy metals settling on sample surfaces. Different methods of filtration were used in order to extract the metals from the surfaces of the samples. The most abundant metals in honeybees and propolis, and on plant and soil samples, were $\mathrm{Sn}$ and $\mathrm{As}(\mathrm{p}<0.0001)$. In air samples0, the most abundant metal was $\mathrm{Pb}$ followed by $\mathrm{Sn}$ $(\mathrm{p}<0.05)$. These findings indicate that the honeybee and its propolis are good indicators for $\mathrm{Sn}$ and As contamination.
\end{abstract}

Keywords: MP-AES, propolis, bioaccumulation, Apis mellifera, bioindicator.

\section{Abelhas e seus produtos como bioindicadores da poluição por metais pesados em Malta}

\begin{abstract}
Resumo
Neste estudo, amostras de abelhas, própolis, ar, solo e plantas foram coletadas em dois locais contrastantes Hal Luqa (área industrial) e L-Imġarr (área agrícola) no continente de Malta. Os metais pesados superficiais foram extraídos das amostras e testados por espectrometria de emissão atômica com plasma de microondas, a fim de determinar as concentrações de Ag, As, $\mathrm{Cd}, \mathrm{Cr}, \mathrm{Cu}, \mathrm{Pb}, \mathrm{Sn}, \mathrm{Zn}, \mathrm{Ni}$ e $\mathrm{Hg}$. As amostras de abelhas e própolis foram digeridas com ácido nítrico e peróxido de hidrogênio e, em seguida, moídas com forno de mufla para preparar soluções minerais. Simultaneamente, os amostradores de ar, o solo e as plantas foram lavados com água desionizada, a fim de extrair os metais pesados depositados nas superfícies das amostras. Diferentes métodos de filtração foram utilizados para extrair os metais das superfícies das amostras. Os metais mais abundantes nas abelhas e própolis e nas amostras de plantas e solo foram Sn e As ( p <0,0001). Nas amostras de ar0, o metal mais abundante foi o $\mathrm{Pb}$, seguido pelo $\mathrm{Sn}(\mathrm{p}<0,05)$. Esses achados indicam que a abelha e sua própolis são bons indicadores de contaminação por Sn e As.
\end{abstract}

Palavras-chave: MP-AES, própolis, bioacumulação, Apis mellifera, bioindicador.

\section{Introduction}

The biodiversity of an island usually evolves with a change in climatic conditions and anthropogenic activities. However, changes in biodiversity and surrounding conditions may pose a threat to the survival of organisms, including sensitive fauna and flora. The honeybee is amongst these susceptible organisms (De la Rúa, Jaffé, Dall'Olio, Muñoz, \& Serrano, 2009).

The Maltese archipelago is a small group of islands situated at the centre of the Mediterranean Sea. Though small, these islands harbour a vast number of plant species (Attard, 2004). The Maltese climate is typically Mediterranean, and defined as arid to semi-arid, which is highly influenced by the 60 surrounding Mediterranean Sea (Sultana \& Falzon, 2002). The climate is bi-seasonal, having warm dry summers and cool wet winters with an annual rainfall of circa $530 \mathrm{~mm}$. The wet season, being from the months of October to March, varies from year to year. Moreover, the islands are subject to prolonged hours of sunshine and mild air temperatures (Schembri, 1997).

The Maltese honeybee (Apis mellifera ruttneri) is an important insect, which has thrived on the islands for many thousands of years (Sheppard, Arias, Grech \& Meixner, 1997). Moreover, honeybees are important locally as they provide essential services for both human activities and ecosystem health (Abrol, 2010; Markle, 2013; 
Suryanarayanan \& Kleinman, 2016; Tautz, Sandeman, \& Heilmann, 2008; Wilson-Rich, Allin, Carreck, \& Quigley, 2014; Attard \& Bugeja Douglas, 2017). Due to rapid anthropogenic changes in the environment locally and globally, honeybee populations are declining with varying degrees of morbidities and mortalities (Bromenshenk et al, 2010; Nikolić et al, 2016). Pressure on land and other factors such as industrial activities lead to the dispersal of heavy metal aerosols, which affect the efficiency of the honeybee both directly and indirectly (Badiou-Bénéteau et al, 2013). The deposition of airborne heavy metal particles occurs via three processes, namely dry deposition, wet deposition and occult deposition, which are enhanced and affected by weather and climatic conditions (Fowler et al, 2004).

Among the harmful substances that are derived from the environment, heavy metals feature significantly in such bee products. Honeybees may take up these metals from the environment in several ways such as via the soil, vegetation, air and water (Brown \& Welton, 2008) which accumulate in honeybees and their products (Devillers \& Pham-Delègue, 2002). Studies focused on metal pollutants derived from industry (Vernet, 1992; Tchounwou, Yedjou, Patlolla, \& Sutton, 2012) which are disseminated by the combustion of gases (Tchounwou et al, 2012; Matin, Kargar \& Buyukisik, 2016), traffic congestion (Di, Hladun, Zhang, Liu, \& Trumble, 2016) and agricultural practices (Swaileh \& Abdulkhaliq, 2013). These ultra-fine fragments of metal particles deposit on various biotic and abiotic surfaces including soils, vegetation, water and pollen. In some instances, these are sometimes inhaled by honeybees during flight (Leita, Muhlbachova, Cesco, Barbattini \& Mondini, 1996). Subsequently honeybees have been considered as ideal indicators for the presence of heavy metals (Balestra, Celli, \& Porrini, 1992; Gagné, 2012; Van der Steen, 2016).

Since its accession to the European Union, Malta has adopted the legal framework that is responsible for monitoring the long-term pollutant levels such as air borne heavy metals, sulphur dioxide levels and particulate matter (Air Quality, 2019). The European Directives, 2001/81/EC, Directive 2004/107/EC, Directive 2008/50/EC and Legal Notice 478 of 2010 on the ambient air quality, are in effect in the Maltese legal system, and the Maltese Environment Resource Authority (ERA) is the responsible into monitor these pollutants in the air (ERA, 2019). To complement this, the aim of the present study was to determine whether the honeybee or its products can be considered as indicators for heavy metal pollution in urban and rural areas.

\section{Materials and Methods}

\section{Areas of study}

The study was conducted at two sites on the island of Malta; one in the south of Malta, Hal Luqa $\left(35.870334^{\circ}, 14.479572^{\circ}\right)$ and the other in the north of Malta, L-Imgarr (Mgarr) $\left(35.930559^{\circ}, 14.373099^{\circ}\right)$. In each location, three healthy and active honeybee hives were chosen. The hives, constructed out of wood to avoid metal contamination, were oriented towards the east avoiding the harsh southern hot wind and the cold prevailing north-westerly wind. The hives were located around
$1 \mathrm{~m}$ from each other and elevated circa half a meter from the ground. The samples were collected during October (2016), December (2016) and February (2017). The first week of the chosen months was used to determine the concentration of metals in dead or dying honeybees, propolis, plant matter, soil and air samples. All samples were then treated accordingly for the determination of metals.

\section{Plant samples}

Typical plant species were collected during the sampling season. The site at Luqa is characterised by crop plants. However, the border of the fields are lined with the cypress tree (Cupressus semprevirens). On the other hand, the site at Mgarr is characterised by the common asphodel (Asphodelus microcarpus). Following the collection of random samples within a five-metre perimeter from the hives, approximately $1.5 \mathrm{~g}$ of plant samples (in triplicates) were place in $50 \mathrm{~mL}$ centrifuge tubes and $30 \mathrm{~mL}$ of de-ionised water was added. Samples were filtered through a Büchner funnel to collect the dissolved metals in the filtrate. The samples were made up to volume in a 50-mL volumetric flask, with de-ionised water.

\section{Soil samples}

Soil samples were also obtained from the surface at both sites within a five-metre perimeter from the hives. The Mgarr soil has a composition mainly coming from a karstland environment of which the soil is classified as being a terra soil, while the Luqa area soils are classified as being carbonate raw soils mainly coming from globigerina limestone deposits found in the area. The soil samples were taken from underneath the beehives, taking only a surface top layer of soil using a plastic shovel. Following the collection of random samples, approximately $5 \mathrm{~g}$ of soil were weighed in $50 \mathrm{~mL}$-centrifuge tubes in triplicates. Samples were then shaken thoroughly and then centrifuged at 2500 rpm for 10 minutes. Clear filtrates were obtained by using a Büchner funnel. The samples were then passed through a $0.22 \mu \mathrm{m}$ filter. The samples were made up to volume in a 50$\mathrm{mL}$ volumetric flask, with de-ionised water.

\section{Air samplers}

The air samplers were placed in triplicates at both sites, approximately half a meter away from each hive selected for the study. The setup is illustrated in Figure 1. The wicks were thoroughly rinsed with de-ionised water, which was collected and added on to the water present in the centrifuge tube. Following coarse filtration in a Büchner funnel, samples were passed through a $0.22 \mu \mathrm{m}$ filter and made up to volume in a $50-\mathrm{mL}$ volumetric flask, using de-ionised water.

\section{Bees and propolis}

Dead bees were collected from the hives entrances and propolis was collected from within the hive. The bees were individually weighed and approximately $0.7 \mathrm{~g}$ of propolis samples were weighed in triplicate. The individual samples were then placed in porcelain crucibles and transferred to a 
hot plate at $90{ }^{\circ} \mathrm{C} .1 \mathrm{~mL}$ of $5 \% \mathrm{HNO}_{3}$ was added to each crucible and allowed to eventually evaporate. $0.5 \mathrm{~mL}$ of $\mathrm{H}_{2} \mathrm{O}_{2}$, were added and allowed to dry. The samples were then placed in a muffle furnace (Wisetherm, Wisd, Laboratory Instruments, Germany) at $500{ }^{\circ} \mathrm{C}$ for four hours. The ashed samples were transferred quantitatively to a $50-\mathrm{mL}$ volumetric flask, by adding $5 \mathrm{~mL}$ of $5 \% \mathrm{HNO}_{3}$, filtered and made to volume with de-ionised water.

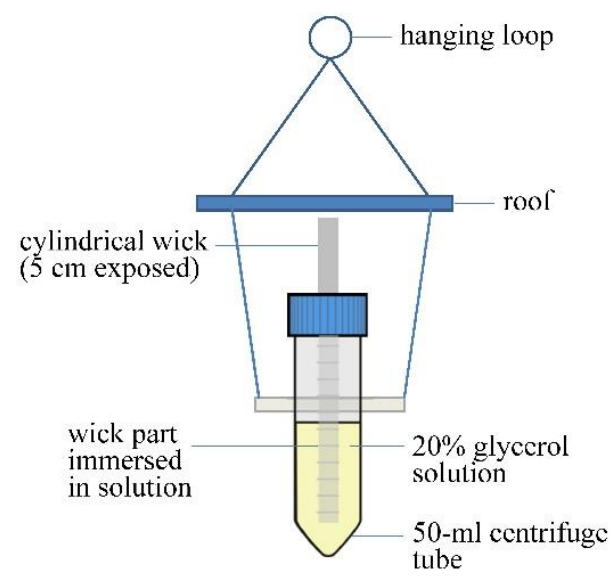

Figure 1. The wick sampler setup.

\section{Heavy metal analysis}

An Agilent 4100 MP-AES (Agilent Technologies, Santa Clara, CA, USA) was used for the analysis of samples for their content of As (metalloid), Ag, Cd, Cr, Cu, Hg, Ni, Pb, Sn and $\mathrm{Zn}$ (metals). The pump was set at a speed of $15 \mathrm{rpm}$, and the stabilization and uptake times were both $15 \mathrm{~s}$. An Agilent OneNeb Pneumatic concentric nebulizer and a double-pass glass cyclonic spray chamber for Agilent MP-AES were used. The metals were calibrated using a standard solution (Multielement Standard Solution 6 for ICP, Sigma-Aldrich, Steinheim, Germany). Calibration curves were setup for such elements. Table 1 shows the limits of detection (LOD) and limits of quantification (LOQ) for the elements under investigation. The LOD and LOQ for each metal were calculated as $3 \mathrm{~s} / \mathrm{m}$ and 10 $\mathrm{s} / \mathrm{m}$ respectively, where $\mathrm{s}$ refers to the standard deviation of the intensity of blank samples and $m$ refers to the slope of the calibration curve for each element. The samples were analysed in triplicates.

Table 1. The respective wavelengths, correlation coefficients $\left(\mathrm{R}^{2}\right)$, limits of detection (LOD) and limits of quantification (LOQ) of $\mathrm{Ag}, \mathrm{As}, \mathrm{Cd}, \mathrm{Cr}, \mathrm{Cu}, \mathrm{Hg}, \mathrm{Ni}, \mathrm{Pb}, \mathrm{Sn}$ and $\mathrm{Zn}$.

\begin{tabular}{ccccc}
\hline Element & $\begin{array}{c}\text { Wavelength } \\
(\mathrm{nm})\end{array}$ & $\mathrm{R}^{2}$ & $\begin{array}{c}\mathrm{LOD} \\
(\mathrm{mg} / \mathrm{kg})\end{array}$ & $\begin{array}{c}\mathrm{LOQ} \\
(\mathrm{mg} / \mathrm{kg})\end{array}$ \\
\hline $\mathrm{Ag}$ & 328.068 & 0.9998 & 0.0285 & 0.0863 \\
$\mathrm{As}$ & 193.695 & 1.0000 & 2.6042 & 7.8916 \\
$\mathrm{Cd}$ & 228.802 & 1.0000 & 0.0067 & 0.0204 \\
$\mathrm{Cr}$ & 425.433 & 0.9999 & 0.0005 & 0.0014 \\
$\mathrm{Cu}$ & 324.754 & 1.0000 & 0.0007 & 0.0022 \\
$\mathrm{Hg}$ & 253.652 & 0.9999 & 0.0793 & 0.2403 \\
$\mathrm{Ni}$ & 352.454 & 0.9999 & 0.0056 & 0.0169 \\
$\mathrm{~Pb}$ & 405.781 & 1.0000 & 0.0169 & 0.0511 \\
$\mathrm{Sn}$ & 317.505 & 0.9999 & 0.0375 & 0.1137 \\
$\mathrm{Zn}$ & 213.857 & 1.0000 & 0.0256 & 0.0775 \\
\hline
\end{tabular}

62

\section{Meteorological Conditions}

The meteorological data for temperature, dew point, humidity, wind speed, pressure and precipitation were extracted from the Wunderground.com (2017) website and recorded. These were correlated with the metal concentrations for the five parameters studied.

\section{Statistical analysis}

Data was statistically analysed using GraphPad Prism ver. 5.0 for Windows (GraphPad Software, San Diego, CA, USA) and XLSTAT version 2014.4.04 (Addinsoft). The Prism software was used for the determination of the level of significance between the means of samples with time and between localities, using one-way ANOVA with the Bonferroni post-hoc test. Pearson's correlation was used to determine any significant relationship between the metal concentrations of the different parameters studied. The significance level was measured at $\mathrm{p}<0.05$.

\section{Results and discussion}

Several studies were conducted on the use of the honeybee as a potential biomarker for environmental pollutants, particularly heavy metals (Formicki, Gren, Stawarz, Zysk \& Gal, 2013; Roman, Madras-Majewska \& Popiela-Pleban, 2011; Matin et al, 2016; Finger, Kelte Filho, Torres \& Quináia, 2014). However, these studies either investigated a limited number of heavy metals or else did not sample other biotic and abiotic parameters alongside the honeybee and its products. This study was conducted to determine the relationship of metals and metalloids on environmental surfaces (soil, plants and atmosphere) with the presence of these elements in the honeybees and propolis within the same temporal and spatial setting. As a result, three sampling times separated by a two-month difference were considered at two different localities that are characterised by an urban environment (Luqa) and a rural environment (Mgarr).

\section{Plant samples}

Although plants accumulate several heavy metals in their internal tissues, the scope of this study was to determine the accumulation of $\mathrm{As}, \mathrm{Ag}, \mathrm{Cd}, \mathrm{Cr}, \mathrm{Cu}, \mathrm{Hg}, \mathrm{Ni}, \mathrm{Pb}, \mathrm{Sn}$ and $\mathrm{Zn}$ on plant surfaces over the leaf boundary layer as was reported previously with gaseous substances (Schreuder, Brewer \& Heine, 2001). In other studies, plants were used as a means of assessing superficial heavy metal deposition (Fowler et al, 2004) and to assess presence of metals on plant surfaces via systemic uptake and elimination through leaf stomata (Clemens, Palmgren, \& Krämer, 2002).

Table 2 shows the deposition of metals found on the surfaces of plant samples and soil in the current study. The major metal depositions observed from plant surface deposits at both sites was Sn and As. Kampouroglou, \& Economou-Eliopoulos (2013) reported an arsenic value of $8.8 \mu \mathrm{g} \mathrm{g}^{-1}$, which is significantly lower than the values reported in the current study. In case of $\mathrm{Pb}, \mathrm{Hg}$ and $\mathrm{Ag}$, we report values of 0.00-11.82, 0.53-2.45 and 1.73-2.86 $\mu \mathrm{g} \mathrm{g}^{-1}$, respectively, for both sites. The values expressed by 
Zhelyazkova, Atanasova, Barakova \& Mihaylova (2010) for $\mathrm{Pb}\left(1.78 \pm 0.09 \mu \mathrm{g} \mathrm{g}^{-1}\right)$, by Kampouroglou \& EconomouEliopoulos (2013) for $\mathrm{Hg}\left(0.02 \mu \mathrm{g} \mathrm{g}^{-1}\right)$ and by Lepp (2012) for $\mathrm{Ag}\left(0.03-0.09 \mu \mathrm{g} \mathrm{g}^{-1}\right)$ were all lower than the levels reported in this study. Low levels of $\mathrm{Ni}$ and Copper $(\mathrm{Cu})$ were reported in the current study (0.47-0.66 and 0.06-0.37 $\mu \mathrm{g} \mathrm{g}^{-1}$, respectively), which were not significantly different at both sites. Both metals reported by Dospatliev, Kostadinov, Mihaylova \& Katrandzhiev (2012) (Ni: $\left.198.0 \pm 0.21 \mu \mathrm{g} \mathrm{g}^{-1}\right)$ and Peris and coworkers (2007) $\left(\mathrm{Cu}: 3.2 \pm 4.1 \mu \mathrm{g} \mathrm{g}^{-1}\right)$ were higher than those of the present study. The metals $\mathrm{Zn}$ and $\mathrm{Cr}$ were not detected in plant deposits at the Luqa site, but present in negligible quantities in the different sampling periods at the Mgarr site (0.00-0.35 and 0.00-0.06 $\mu \mathrm{g} \mathrm{g}^{-1}$, respectively). Cd was not detected in plant deposits at both sites. However, for these three metals respectively, Kampouroglou \& Economou-Eliopoulos (2013) (Zn: $\left.74.8 \mu \mathrm{g} \mathrm{g}^{-1}\right)$, Onder \& Dursun (2006) (Cr: $13.06 \mu \mathrm{g}$ $\mathrm{g}^{-1}$ ) and Baranowska, Srogi, Włochowicz \& Szczepanik (2002) (Cd: $\left.120 \pm 0.05 \mu \mathrm{g} \mathrm{g}^{-1}\right)$ reported much higher levels. In previous studies, plants have been suggested as good indicators of environmental change (Baranowska et al, 2002). However, it is worth noting that most previous studies practically report the endogenous accumulation of heavy metals rather than the exogenous accumulation.

\section{Soil samples}

Various studies investigated surface heavy metal contents of soils, some of which can be found naturally. However, this depends on soil type as for example, volcanic soils naturally contain metals (Ordonez, Loredo, De Miguel $\&$ Charlesworth, 2003). Previous studies defined superficial soil sampling as the sampling of the first centimetres of soil in which superficial deposition of most metals occurs (Xian, Wang \& Chen, 2015). A study, conducted in anthropogenic regions of Spain close to smelters and factories, showed that there is the deposition of heavy metal dust particles within the top layer of surrounding soils (Ordonez et al, 2003).

Table 2. The deposition of metals in $\mu \mathrm{g} \mathrm{g}^{-1}$ on plant material and soil for the two localities at three sampling dates.

\begin{tabular}{|c|c|c|c|c|c|c|c|}
\hline \multirow[t]{2}{*}{ Metal } & \multirow[t]{2}{*}{ Locality } & \multicolumn{3}{|c|}{ plant material } & \multicolumn{3}{|c|}{ soil } \\
\hline & & Oct-16 & Dec-16 & Feb-17 & Oct-16 & Dec-16 & Feb-17 \\
\hline \multirow{2}{*}{$\mathrm{Ag}$} & Mġarr & $1.81 \pm 0.05$ & $1.81 \pm 0.05$ & $1.73 \pm 0.02$ & $0.26 \pm 0.02$ & $0.33 \pm 0.01$ & $0.4 \pm 0.00$ \\
\hline & Luqa & $2.11 \pm 0.05$ & $2.49 \pm 0.08$ & $2.86 \pm 0.04$ & $0.45 \pm 0.00$ & $0.4 \pm 0.01$ & $0.62 \pm 0.01 * * *$ \\
\hline \multirow{2}{*}{$\mathrm{Pb}$} & Mġarr & $9.46 \pm 0.04$ & $11.82 \pm 0.07$ & ND*** & $1.39 \pm 0.01$ & $2.02 \pm 0.01$ & ND*** \\
\hline & Luqa & $10.91 \pm 0.10 * * *$ & ND & ND & $2.26 \pm 0.03 * * *$ & ND & ND \\
\hline \multirow{2}{*}{ As } & Mġarr & $7.52 \pm 4.19$ & $35.61 \pm 5.17 * * *$ & $27.19 \pm 13.94$ & $1.05 \pm 0.68$ & $5.63 \pm 0.97$ & $5.99 \pm 2.59$ \\
\hline & Luqa & $27.40 \pm 2.88$ & $31.43 \pm 16.07$ & ND*** & $5.78 \pm 0.26$ & $6.21 \pm 2.07$ & $3.04 \pm 1.71$ \\
\hline \multirow{2}{*}{$\mathrm{Zn}$} & Mġarr & $0.35 \pm 0.05 * * *$ & $0.01 \pm 0.01$ & ND & $0.13 \pm 0.00$ & ND & $0.14 \pm 0.01$ \\
\hline & Luqa & ND & ND & ND & ND & ND & $0.10 \pm 0.02$ \\
\hline \multirow{2}{*}{$\mathrm{Cd}$} & Mġarr & ND & ND & ND & ND & ND & ND \\
\hline & Luqa & ND & ND & ND & ND & ND & ND \\
\hline \multirow{2}{*}{$\mathrm{Cr}$} & Mgarr & $0.06 \pm 0.01 * * *$ & ND & ND & ND & ND & ND \\
\hline & Luqa & ND & ND & ND & $0.01 \pm 0.00 * * *$ & ND & ND \\
\hline \multirow{2}{*}{$\mathrm{Cu}$} & Mġarr & $0.37 \pm 0.00 * * *$ & $0.11 \pm 0.01$ & $0.06 \pm 0.00$ & $0.05 \pm 0.00$ & $0.02 \pm 0.00 * * *$ & $0.03 \pm 0.00$ \\
\hline & Luqa & $0.09 \pm 0.00 * * *$ & $0.19 \pm 0.00$ & $0.15 \pm 0.00$ & $0.14 \pm 0.00 * * *$ & $0.06 \pm 0.00$ & $0.06 \pm 0.00$ \\
\hline \multirow{2}{*}{$\mathrm{Hg}$} & Mġarr & $1.80 \pm 0.18$ & $1.38 \pm 0.16$ & $2.22 \pm 0.12$ & $0.52 \pm 0.02$ & $0.14 \pm 0.05^{* *}$ & $0.48 \pm 0.03$ \\
\hline & Luqa & $0.53 \pm 0.07 * * *$ & $1.79 \pm 0.11$ & $2.45 \pm 0.08$ & $0.22 \pm 0.08$ & $0.19 \pm 0.02$ & $0.53 \pm 0.05^{* *}$ \\
\hline \multirow{2}{*}{$\mathrm{Ni}$} & Mġarr & $0.48 \pm 0.00$ & $0.64 \pm 0.02$ & $0.47 \pm 0.01$ & $0.10 \pm 0.00$ & $0.1 \pm 0.00$ & $0.1 \pm 0.00$ \\
\hline & Luqa & $0.50 \pm 0.01$ & $0.66 \pm 0.01 * * *$ & $0.53 \pm 0.00$ & $0.17 \pm 0.00 * * *$ & $0.11 \pm 0.00$ & $0.14 \pm 0.00$ \\
\hline \multirow{2}{*}{$\mathrm{Sn}$} & Mġarr & $37.23 \pm 0.10$ & $44.39 \pm 0.37$ & $41.32 \pm 0.65$ & $5.64 \pm 0.03 * * *$ & $8.06 \pm 0.07$ & $8.98 \pm 0.06$ \\
\hline & Luqa & $42.60 \pm 0.43$ & $52.77 \pm 0.21$ & $46.27 \pm 0.80$ & $9.04 \pm 0.10$ & $8.55 \pm 0.03$ & $10.24 \pm 0.12$ \\
\hline
\end{tabular}

*** $\mathrm{p}<0.001$, significant differences were considered between sampling sites and sampling dates; ND=Not Detected.

The order of metal abundance on the soil surface mirrored that obtained for the plant surface (Table 2). However, the magnitude of their abundance on the soil surface is relatively lower. The highest values were exhibited by $\mathrm{Sn}, \mathrm{As}$ and $\mathrm{Pb}$ at both sites (5.64-10.24, 1.05-6.21 and 0.00-2.26 $\left.\mu \mathrm{g} \mathrm{g} \mathrm{g}^{-1}\right)$. Kampouroglou \& Economou-Eliopoulos (2013) reported that in Greece the As and $\mathrm{Pb}$ levels were 231 and $58 \mu \mathrm{g} \mathrm{g}^{-1}$, respectively, being much higher than the levels expressed in this current study. The levels of $\mathrm{Ag}, \mathrm{Hg}, \mathrm{Ni}, \mathrm{Zn}$ and $\mathrm{Cu}$ were present in this decreasing order of abundance $(<0.62,<0.53$, $<0.17,<0.14$ and $<0.14 \mu \mathrm{g} \mathrm{g} \mathrm{g}^{-1}$, respectively) with insignificant differences between the two locations. Kampouroglou \& Economou-Eliopoulos (2013) expressed an $\mathrm{Hg}$ level of $0.1 \mu \mathrm{g}$ $\mathrm{g}^{-1}$, which was lower than that found in the current study. However, the levels of $\mathrm{Ni}, \mathrm{Zn}$ and $\mathrm{Cu}$ reported by Peris et al
(2007) (Ni: 0.49 $\pm 0.17 \mu \mathrm{g} \mathrm{g}^{-1}$ ) and Çelik, Kartal, Akdoğan \& Kaska (2005) (Zn: 81.23 \pm 9.12 and Cu: $17.19 \pm 0.95 \mu \mathrm{g} \mathrm{g}^{-1}$ ) were higher than those for the present study. The levels of $\mathrm{Cr}$ and $\mathrm{Cd}$ were very low $\left(<0.01 \mu \mathrm{g} \mathrm{g}^{-1}\right.$ and not detected, respectively), where only $\mathrm{Cr}$ was reported to be present at Luqa. The level of metal contamination may be attributed to the pollution status of a site. In a study conducted by Maas et al (2010), the level of $\mathrm{Cr}$ was $138.0 \pm 5.0 \mu \mathrm{g} \mathrm{g}^{-1}$, being significantly higher than levels obtained in this study, whereas Peris et al (2007) showed that Cd levels were $0.10 \pm 0.032 \mu \mathrm{g} \mathrm{g}^{-1}$, which are significantly low. Soil samples differ in mineral extraction levels on a regional scale. Consequently, some results may vary depending on soil contamination from other sources other than atmospheric pollution. 


\section{Air samplers}

The air samples gathered for both sites were allowed on site for a week in order to obtain a 7-day average. To prevent water loss from the tubes, glycerol was added. After the samples were gathered, they were sealed with a cap to avoid any liquid from leaking. Previous studies utilised a different sampling devices such as the high volume air sampler and glass fibre filter (Handika, Purwaningrum \& Lestari, 2019; Maître et al, 2003).

Table 3 shows the deposition fluxes of metals found on air samplers in this current study. The metal with the highest flux in air was $\mathrm{Pb}\left(18369.98 \pm 6325.29 \mu \mathrm{g} / \mathrm{m}^{2} /\right.$ day $)$. The level of $\mathrm{Pb}$ at the Mgarr site was approximately three times greater than that at the Luqa site, in spite that the former site has a more rural characteristic than the latter $(\mathrm{p}<0.001)$. The metals $\mathrm{Sn}, \mathrm{Ni}$ and As followed (5527.03-10271.68, 1326.12-10918.42 and $0.00-9119.33 \mu \mathrm{g} / \mathrm{m}^{2} /$ day).

The metals $\mathrm{Zn}$ and Ag exhibited moderate deposition fluxes of $0.00-1153.67$ and $427.65 \pm 30.47 \mu \mathrm{g} / \mathrm{m}^{2} /$ day, in this present study. In Romania, Zn levels were up to $30.4 \pm 1.4 \mathrm{ppm}$ (Popescu et al, 2010), much lower than the local zinc levels. The levels of $\mathrm{Hg}, \mathrm{Cu}$ and $\mathrm{Cr}$ were present in this decreasing order of deposition flux (0.00-234.49, 18.40-86.51, and 0.00$28.84 \mu \mathrm{g} / \mathrm{m}^{2} /$ day, respectively) with insignificant differences between the two locations. In a study conducted by Krmar, Radnović \& Frontasyeva (2012) conducted in Serbia, the level of $\mathrm{Cu}$ was $11.1 \mathrm{ppm}$. much lower than in this study. Cadmium was not detected in the air samples at both sites. Studies regarding air samples are very limited. However, air pollution is a major concern worldwide especially in urban areas.

\section{Honeybees}

As stated by various other studies, honeybees are good samplers of environmental changes and heavy metal deposition (Charlesworth, Everett, McCarthy, Ordóñez, \& de Miguel, 2003). As with other organisms that thrive in an open environment, bees can accumulate numerous toxic chemicals over time. In the present study, although morbidity and mortality of bees were taken into consideration, only dead bees at the entrance of hives were sampled.

Table 4 shows the accumulation of metals in honeybees and propolis for the two sites under study in different sampling periods. The two major metals of concern in honeybees were Sn and As (74.40-358.242 and 26.48-92.42 $\mu \mathrm{g} \mathrm{g}^{-1}$, respectively).

Table 3. The deposition flux of metals in $\mu \mathrm{g} / \mathrm{m}^{2} /$ day in air samples for the two localities at three sampling dates

\begin{tabular}{|c|c|c|c|c|}
\hline Metal & Locality & Oct-16 & Dec-16 & Feb-17 \\
\hline \multirow{2}{*}{$\mathrm{Ag}$} & Mġarr & $336.75 \pm 6.27$ & $377.54 \pm 10.13 * *$ & $397.08 \pm 7.90$ \\
\hline & Luqa & $426.29 \pm 13.18$ & $538.42 \pm 11.83$ & $489.85 \pm 25.61$ \\
\hline \multirow{2}{*}{$\mathrm{Pb}$} & Mġarr & $18398.90 \pm 65.03$ & $16255.55 \pm 44.60$ & $48824.32 \pm 76.33 * * *$ \\
\hline & Luqa & $8691.14 \pm 20.11$ & $8988.43 \pm 22.25$ & $9061.47 \pm 5.70$ \\
\hline \multirow{2}{*}{ As } & Mġarr & $0.00 \pm 0.00$ & $7528.74 \pm 543.48$ & $9119.33 \pm 2467.59$ \\
\hline & Luqa & $5057.10 \pm 673.53$ & $7567.25 \pm 2371.02$ & $5193.89 \pm 2759.48$ \\
\hline \multirow{2}{*}{$\mathrm{Zn}$} & Mġarr & $1153.67 \pm 41.40$ & $98.65 \pm 15.10$ & $184.03 \pm 15.60$ \\
\hline & Luqa & $288.75 \pm 12.99$ & $96.76 \pm 12.73$ & $0.00 \pm 0.00$ \\
\hline \multirow{2}{*}{$\mathrm{Cd}$} & Mġarr & $0.00 \pm 0.00$ & $0.00 \pm 0.00$ & $0.00 \pm 0.00$ \\
\hline & Luqa & $0.00 \pm 0.00$ & $0.00 \pm 0.00$ & $0.00 \pm 0.00$ \\
\hline \multirow{2}{*}{$\mathrm{Cr}$} & Mġarr & $4.55 \pm 2.28$ & $0.00 \pm 0.00$ & $0.00 \pm 0.00$ \\
\hline & Luqa & $0.00 \pm 0.00$ & $28.84 \pm 5.09 * * *$ & $0.00 \pm 0.00$ \\
\hline \multirow{2}{*}{$\mathrm{Cu}$} & Mġarr & $23.34 \pm 0.66$ & $18.40 \pm 0.50$ & $86.51 \pm 0.57 * * *$ \\
\hline & Luqa & $22.58 \pm 0.19$ & $36.62 \pm 0.19 * * *$ & $20.30 \pm 0.68$ \\
\hline \multirow{2}{*}{$\mathrm{Hg}$} & Mġarr & $18.59 \pm 11.98$ & $0.00 \pm 0.00$ & $0.00 \pm 0.00$ \\
\hline & Luqa & $3.60 \pm 3.60 * * *$ & $192.37 \pm 26.26$ & $234.49 \pm 41.75$ \\
\hline \multirow{2}{*}{$\mathrm{Ni}$} & Mġarr & $3640.11 \pm 11.12$ & $3157.47 \pm 2.01$ & $10918.42 \pm 13.02 * * *$ \\
\hline & Luqa & $1326.12 \pm 4.12$ & $1385.51 \pm 2.11$ & $1404.48 \pm 3.12$ \\
\hline \multirow{2}{*}{$\mathrm{Sn}$} & Mgarr & $5527.03 \pm 58.43 * * *$ & $7850.88 \pm 54.24$ & $8059.38 \pm 60.51$ \\
\hline & Luqa & $7877.63 \pm 120.05$ & $10271.68 \pm 110.24 * * *$ & $8499.72 \pm 54.13$ \\
\hline
\end{tabular}

In a study conducted by Van der Steen (2016), in the Netherlands the level of Sn $\left(0.39 \mu \mathrm{g} \mathrm{g}{ }^{-1}\right)$ was significantly lower than that reported in this present study. Bertholf \& Pilson (1941) observed toxicity of honeybees with arsenic, in the arsenate form. $\mathrm{Ni}, \mathrm{Pb}, \mathrm{Zn}$ and $\mathrm{Ag}$ were moderately expressed in honeybees $(0.69-105.16,0.00-69.94,2.29-19.94$ and 3.42$17.19 \mu \mathrm{g} \mathrm{g}^{-1}$, respectively) with the Mgarr site showing higher accumulation of these metals in the honeybees. $\mathrm{Ni}, \mathrm{Pb}$ and $\mathrm{Zn}$ levels were lower in other studies compared to this current study. Other studies by Porrini et al (2003) (Ni: 0.01$\left.0.40 \mu \mathrm{g} \mathrm{g}^{-1}\right)$, Conti \& Botré (2001) (Pb: $\left.0.61 \mu \mathrm{g} \mathrm{g}^{-1}\right)$ and (Roman, 2010) (Pb: $1.98 \mu \mathrm{g} \mathrm{g}^{-1}$ ) reported lower values in honeybees. On the other hand, a study conducted by Zhelyazkova et al (2010) shows that the Zn level was 84.08 
$\pm 8.41 \mu \mathrm{g} \mathrm{g}^{-1}$, as opposed to findings in the present study. In a study by Borsuk, Paleolog, Olszewski \& Strachecka (2013), it was reported that honeybees have a tendency to accumulate silver in their bodies, if this is present in the environment.

Minor metals include $\mathrm{Cu}, \mathrm{Hg}$ and $\mathrm{Cr}$, with insignificant differences between sites. In Poland, the amount of copper found in honeybees was $22.6 \mu \mathrm{g} \mathrm{g}^{-1}$ (Roman, 2010). This was particularly high for bees in urbanized areas. In the city of Rome, Conti \& Botré (2001) observed a Cr concentration of
$0.3 \mu \mathrm{g} \mathrm{g}^{-1}$ in honeybees, which was double the amount observed in this present study. Cd was not detected in local honeybee samples. Roman (2010) reported a value of 0.65 $\mu \mathrm{g} \mathrm{g}^{-1}$ for $\mathrm{Cd}$. Several studies were performed on honeybees by a number of research groups (Porrini et al, 2003; Gutiérrez et al, 2015; Van der Steen, 2016; Zhelyazkova et al, 2010; Perugini et al, 2010; Satta et al, 2012; Roman, 2010; Conti \& Botrè, 2001). In this study Sn was the highest, followed by $\mathrm{As}, \mathrm{Ni} \mathrm{Pb}, \mathrm{Zn}, \mathrm{Cu}$. In contrast $\mathrm{Cd}$ has also been found to be present in negligible amounts in honey bees.

Table 4. The concentration of metals in $\mu \mathrm{g} \mathrm{g}^{-1}$ in honeybees and propolis for the two localities at three sampling dates.

\begin{tabular}{|c|c|c|c|c|c|c|c|}
\hline \multirow{3}{*}{ Metal } & \multirow{3}{*}{ Locality } & \multicolumn{3}{|c|}{ honeybees } & \multicolumn{3}{|c|}{ propolis } \\
\hline & & & & & Oct-16 & Dec-16 & Feb-17 \\
\hline & & Oct-16 & Dec-16 & Feb-17 & & & \\
\hline \multirow{2}{*}{$\mathrm{Ag}$} & Mġarr & $17.19 \pm 0.17 * * *$ & $5.05 \pm 0.09$ & $5.17 \pm 0.05$ & $6.12 \pm 0.09$ & $5.39 \pm 0.05$ & $5.16 \pm 0.16$ \\
\hline & Luqa & $7.51 \pm 0.17$ & $3.42 \pm 0.07 * * *$ & $9.13 \pm 0.12$ & $5.59 \pm 0.12$ & $4.77 \pm 0.07$ & $6.49 \pm 0.11$ \\
\hline \multirow[b]{2}{*}{$\mathrm{Pb}$} & Mġarr & $69.94 \pm 0.53 * * *$ & ND & ND & $\begin{array}{c}28.50 \pm 0.29 * * \\
*\end{array}$ & ND & ND \\
\hline & Luqa & $33.23 \pm 0.29 * * *$ & ND & ND & $\begin{array}{c}27.28 \pm 0.10 * * \\
*\end{array}$ & ND & ND \\
\hline \multirow{2}{*}{ As } & Mġarr & $26.48 \pm 23.65$ & $76.86 \pm 7.16$ & $59.19 \pm 28.51$ & $38.65 \pm 17.57$ & $58.83 \pm 26.72$ & $45.20 \pm 23.05$ \\
\hline & Luqa & $92.42 \pm 23.96$ & $48.44 \pm 15.87$ & $31.16 \pm 21.07$ & $65.90 \pm 21.71$ & $50.50 \pm 26.19$ & $42.02 \pm 23.85$ \\
\hline \multirow{2}{*}{$\mathrm{Zn}$} & Mgarr & $19.94 \pm 0.50 * * *$ & $5.31 \pm 0.04$ & $5.42 \pm 0.37$ & $3.60 \pm 0.87 * * *$ & $29.62 \pm 0.19$ & $51.97 \pm 0.30$ \\
\hline & Luqa & $7.06 \pm 0.08$ & $2.67 \pm 0.04$ & $2.29 \pm 0.13$ & $7.90 \pm 0.06$ & $14.31 \pm 0.19$ & $3.08 \pm 0.01 * * *$ \\
\hline \multirow{2}{*}{$\mathrm{Cd}$} & Mġarr & ND & ND & ND & ND & ND & ND \\
\hline & Luqa & ND & ND & ND & ND & ND & ND \\
\hline \multirow{2}{*}{$\mathrm{Cr}$} & Mgarr & $0.74 \pm 0.07 * * *$ & ND & ND & $0.51 \pm 0.03 * *$ & $0.31 \pm 0.02$ & $0.22 \pm 0.00$ \\
\hline & Luqa & $0.03 \pm 0.03 * *$ & ND & ND & $0.33 \pm 0.02 * * *$ & ND & ND \\
\hline \multirow{2}{*}{$\mathrm{Cu}$} & Mġarr & $5.00 \pm 0.05 * * *$ & $1.09 \pm 0.02$ & $0.92 \pm 0.00$ & $1.42 \pm 0.01 * *$ & $1.18 \pm 0.00$ & $1.17 \pm 0.01$ \\
\hline & Luqa & $2.26 \pm 0.01 * * *$ & $0.69 \pm 0.00$ & $0.89 \pm 0.01$ & $0.72 \pm 0.01$ & $0.69 \pm 0.01$ & $0.65 \pm 0.00$ \\
\hline \multirow{2}{*}{$\mathrm{Hg}$} & Mġarr & ND & $1.01 \pm 0.65$ & $1.58 \pm 0.33$ & ND & $0.60 \pm 0.14$ & ND \\
\hline & Luqa & ND & $0.37 \pm 0.19$ & $5.40 \pm 0.28 * * *$ & $1.66 \pm 0.59$ & $3.12 \pm 0.59$ & $0.55 \pm 0.43$ \\
\hline \multirow{2}{*}{$\mathrm{Ni}$} & Mgarr & $105.16 \pm 0.55 * * *$ & $2.93 \pm 0.03$ & $1.06 \pm 0.01$ & $1.47 \pm 0.03 * *$ & $1.22 \pm 0.01$ & $1.10 \pm 0.02$ \\
\hline & Luqa & $1.48 \pm 0.02$ & $0.69 \pm 0.03$ & $1.32 \pm 0.06$ & $1.26 \pm 0.04 * *$ & $1.03 \pm 0.03$ & $0.89 \pm 0.03$ \\
\hline \multirow{2}{*}{$\mathrm{Sn}$} & Mgarr & $358.24 \pm 1.07 * * *$ & $104.33 \pm 1.25$ & $100.14 \pm 1.06$ & $133.47 \pm 0.86$ & $108.96 \pm 0.17$ & $119.69 \pm 0.76$ \\
\hline & Luqa & $153.07 \pm 0.86$ & $74.40 \pm 0.28 * * *$ & $136.70 \pm 1.57$ & $117.41 \pm 0.66$ & $102.99 \pm 0.97$ & $100.76 \pm 1.78$ \\
\hline
\end{tabular}

*** $\mathrm{p}<0.001$, significant differences were considered between sampling sites and sampling dates; ND=Not Detected

\section{Propolis}

Several studies determine the presence of minerals and toxic metals in propolis (González-Martín et al, 2015; Ferreira et al, 2019). Studies have shown that propolis is a good indicator for both bee and plant metal accumulation. Bees gather propolis from plant sap, buds and leaves. These are sticky surfaces that are prone to superficial heavy metal accumulation. The resin is collected by bees to produce propolis. Many studies have used propolis as a means of indicating environmental change (Finger et al, 2014; Maragou, Pavlidis, Karasali \& Hatjina, 2017).

As with the other parameters, $\mathrm{Sn}$ was the main metal present in propolis samples (Table 4), showing no significant differences between sites. Although very few studies consider Sn as an analytical metal, Bonvehí \& Bermejo (2013) reported a level of $90.8 \pm 14.2 \mu \mathrm{g} \mathrm{g}^{-1}$ in Spanish propolis. The second metal to exhibit a significant level as compared to the rest was As (38.65-65.90 $\mathrm{g} \mathrm{g} \mathrm{g}^{-1}$ ). In Turkey, Matin et al (2016) found an arsenic level of $146.24 \mu \mathrm{g} \mathrm{g}^{-1}$ in propolis, being higher than the levels found in the current study. Metals that have moderately accumulated in propolis include $\mathrm{Zn}, \mathrm{Pb}$ and $\mathrm{Ag}$ (3.08-51.97, 0.00-28.50 and 4.77-6.49 $\mu_{\mathrm{g} \mathrm{g}}{ }^{-1}$, respectively). The level of $\mathrm{Zn}$ in the current study concurs with that in propolis from Brazil $\left(20 \pm 0.01 \mu \mathrm{g} \mathrm{g}^{-1}\right.$, Finger et al, 2014) but is lower than that in propolis from Chile and Spain $(62.6 \mu \mathrm{g}$ $\mathrm{g}^{-1}$, González-Martín et al, 2015).

In a study conducted in Rome, the $\mathrm{Pb}$ level found in propolis was $1.06 \mu \mathrm{g} \mathrm{g}^{-1}$ (Conti \& Botrè, 2001), much lower than the levels found in the current study. Minor metals in local propolis include $\mathrm{Ni}, \mathrm{Cu}, \mathrm{Cr}$ and $\mathrm{Hg}$, with insignificant differences between sites. The Ni level in propolis reported by González-Martín et al (2015) was relatively similar (1.5 $\mu \mathrm{g} \mathrm{g}^{-1}$ ) to that of local propolis. $\mathrm{Cu}$ was not detected in Brazilian propolis (Finger et al, 2014) but was found in Chilean and Spanish propolis in a concentration of $1.8 \mu \mathrm{g} \mathrm{g}^{-}$ ${ }^{1}$ (González-Martín et al, 2015). The level of $\mathrm{Cr}$ in local propolis is lower than that found level in Italian $\left(2.48 \mu \mathrm{g} \mathrm{g}^{-1}\right.$, Conti \& Botrè, 2001), Chilean and Spanish propolis $(3.7 \mu \mathrm{g}$ $\mathrm{g}^{-1}$, González-Martín et al, 2015) and in Brazilian propolis $\left(5.53 \pm 3.53 \mu \mathrm{g} \mathrm{g}^{-1}\right.$, Finger et al, 2014). Matin et al (2016) did 
not detect mercury in propolis in industrial areas. As with other parameters considered in this present study, $\mathrm{Cd}$ was not detected in propolis. The $\mathrm{Cd}$ levels were found in Brazilian propolis $\left(0.13 \pm 0.17 \mu \mathrm{g} \mathrm{g}^{-1}\right.$, Finger et al, 2014) and more significantly in Turkish propolis $\left(76.681 \mu \mathrm{g} \mathrm{g}^{-1}\right.$, Matin et al, 2016). These studies relate the metallic environmental pollutants to propolis, which is one of the main hive products.

\section{Sampling dates and meteorological conditions}

As previously mentioned, three sampling times were taken for the duration of this study. The study period represents a transition between the hot dry climate and the cool wet climate typical of the Maltese Islands. Table 5 illustrates the average values for meteorological parameters. The month of September was still persistently hot with a lack of rain, resulting in hot and dry soils. In spite of this, humidity is normally elevated at this time of the year. December represents a cooler weather with episodes of rain and high humidity. The month of February is generally cooler as indicated in Table 5 . At this time of the year the soils are usually cool and wet.

Table 5. Meteorological conditions ${ }^{1}$ during the study period.

\begin{tabular}{lccc}
\hline \multicolumn{1}{c}{ Parameter } & Oct 2016 & Dec 2016 & Feb 2017 \\
\hline Temp $\left({ }^{\circ} \mathrm{C}\right)$ & $22.9 \pm 0.42^{* * *}$ & $15.9 \pm 0.42 * * *$ & $12.5 \pm 0.48^{* * * *}$ \\
Dew Pt $\left({ }^{\circ} \mathrm{C}\right)$ & $17.5 \pm 0.91 * *$ & $13.2 \pm 0.95 * *$ & $9.27 \pm 0.72 * *$ \\
Humidity $(\%)$ & $72.4 \pm 2.92 *$ & $84.9 \pm 2.53$ & $81.5 \pm 2.45$ \\
Wind Spd (mph) & $12.2 \pm 1.38$ & $11.5 \pm 1.85$ & $17.9 \pm 3.91$ \\
Pressure (mmHg) & $1004 \pm 0.81$ & $1015 \pm 1.138^{* *}$ & $1003 \pm 1.50$ \\
Precipitation (mm & ND & $1.24 \pm 0.63$ & $0.28 \pm 0.21$ \\
\hline
\end{tabular}

${ }^{1}$ Data extracted from Wunderground.com (2017). * $\mathrm{p}<0.05^{* *} \mathrm{p}<0.01 ; * * *$ $\mathrm{p}<0.001$.

The purpose of meteorological data observation was to determine any correlation with the accumulation of metals in the respective samples. Some metals tend to be in a higher concentration in air samples during dry weather, such as Zn. However, others tend to prevail more in wet weather such as $\mathrm{Pb}, \mathrm{As}, \mathrm{Cu}, \mathrm{Hg}$ and $\mathrm{Ni}$. This goes in agreement with similar studies showing the deposition of metals under dry and wet conditions (Golomb, Ryan, Eby, Underhill \& Zemba, 1997).

Some metals tend to accumulate in soil during the dry season (Sabin, Lim, Stolzenbach \& Schiff, 2006), indicating that these are carried deeper into the soil as precipitation increases. Such metals include $\mathrm{Pb}, \mathrm{Cr}, \mathrm{Cu}, \mathrm{Ni}$ and $\mathrm{Sn}$. This indicates that precipitation results in a rapid deposition of metals from the air to a surface. Some metals tend to have a high deposition on plant surfaces during the dry season (Sakata \& Marumoto, 2004). In this current study such metals included $\mathrm{Pb}, \mathrm{Zn}, \mathrm{Cr}$ and $\mathrm{Cu}$. Parallel to the deposition flux on soil surfaces, there was also a rapid deposition of metals from the air to a surface.

During this experiment the honeybees accumulated most of the metals during the dry season, presenting the ideal conditions for bees to forage on flora. Most probably there is contact contamination of the bee from surfaces. Internal contamination would have been through the nectar and resins from plants and trees, which would be more evident during the wet season when plant take up and then accumulate these metals in matrices such as nectar and resins. It was observed that such metals included $\mathrm{Ag}, \mathrm{As}, \mathrm{Pb}, \mathrm{Zn}, \mathrm{Cr}, \mathrm{Cu}, \mathrm{Ni}$ and $\mathrm{Sn}$. Propolis followed a similar pattern as the honeybee metal accumulation indicating that there is a transfer of these metals to the bee product. These include most metals, mainly $\mathrm{Ag}, \mathrm{As}, \mathrm{Pb}, \mathrm{Zn}, \mathrm{Cr}, \mathrm{Cu}$, Ni and $\mathrm{Sn}$.

\section{Comparison between metals}

In order to determine any significant levels of heavy metals in the Maltese environment, the three sampling periods were combined for each location, and the latter investigated for any significant differences. There were no statistical differences between the locations for all metals except for $\mathrm{Pb}(\mathrm{p}<0.001)$ for air samples, with the Mgarr $\mathrm{Pb}$ level being much higher than that at Luqa. There were no statistical differences between the locations for all metals for bee, plant, propolis and soil samples. The metal concentrations were correlation for the different parameters using the Pearson Correlation.

Table 6 shows significantly positive and negative correlations. Sn features in several parameter-parameter correlations. However, this shows a positive correlation for Air-Plant, Plant-Bee and Bee-Propolis. This indicates that airborne Sn may be transferred to bee products from plants via the honeybee. In the case of $\mathrm{Zn}$, positive correlations were observed for air-plant, plant-bee, bee-air. This indicates the airborne effects of $\mathrm{Zn}$ on both plant material and bees.

Table 6. Metal concentration correlations between the parameters studied.

\begin{tabular}{lcccc} 
& Bee & Propolis & Soil & Plant \\
\hline \multirow{2}{*}{ Air } & $\mathrm{Sn}^{*}, \mathrm{Zn}$ & $\mathrm{Sn}^{*}$ & $\mathrm{Ag}, \mathrm{As}$ & $\mathrm{Sn}, \mathrm{Zn}, \mathrm{Ag}$ \\
& $(0)$ & $(-1)$ & $(2)$ & $(3)$ \\
Bee & & $\mathrm{Sn}, \mathrm{Ag}, \mathrm{As}, \mathrm{Ni}$, & $\mathrm{Sn}$ *, $\mathrm{As}, \mathrm{Cr}, \mathrm{Sn}, \mathrm{Zn}$, \\
& & $\mathrm{Pb}(5)$ & $\mathrm{Cr}(1)$ & $\mathrm{As}, \mathrm{Cu}$, \\
Propolis & & & $\mathrm{Sn}^{*}, \mathrm{Cr}$, & $\mathrm{As}, \mathrm{Cr}$ \\
& & & $\mathrm{Hg}^{*}(-1)$ & $(2)$ \\
Soil & & & & $\mathrm{Ag}, \mathrm{As}$, \\
& & & & $\mathrm{Cr}, \mathrm{Hg}, \mathrm{Pb}$ \\
\hline
\end{tabular}

*Negative correlations. Values in brackets show the correlation index for each parameter.

However, this is not reflected in the accumulation of $\mathrm{Zn}$ in propolis by the bee. Ag was observed to be correlated between Air-Soil, Air-Plant, Propolis-Bee and Plant-Soil. This shows that Ag has no preferential accumulation, as it is found in bees, their products and their surroundings. $\mathrm{Cr}$ shows correlations between Bee-Soil, Bee-Plant, PropolisSoil, Propolis-Plant and Plant-Soil. This shows that Cr accumulation in the parameters tested mainly depended on deposition of this metal rather than its dispersion in air. Considering the parameter-parameter correlations, the index shows that the bee-propolis, plant-propolis and soilplant are highly correlated with at least five metals. This suggests the movement of metals from soil and plant material to bees, and finally to the finished product, being propolis. 


\section{Conclusion}

In this study various metals were studied for their potential surface deposition and accumulation in air, plant material, soil, bees and propolis. Although the two locations represented the urban (Luqa) and the rural (Mgarr) environments present on the islands, there were no significant differences observed for all the metals studied except for lead in air samples. Unexpectedly, this metal was more abundant in the rural setup. It is worth noting that although the two locations were set at a distance, the island of Malta is so small that wind drifts and other climatic factors may decrease have influenced the distribution and deposition of certain metals in the environment. Nonetheless, it was observed that the honeybee and its product, propolis, can be used as bioindicators for air pollution. The setting up of the system does not require any elaborate equipment. In principle, dead honeybees collected from outside the hive and propolis from inside the hive can be done periodically and samples analysed using a metal analyser. Additional plant, soil and air samples could be collected in order to re-inforce the findings. This study could be extended futher to encompass more hive products that may be bioaccumulateed in the honey bee.

\section{References}

Abrol, D. (2010). Pollination Biology. Springer Science+Business Media B.V. The Netherlands. doi: 10.1007/978-94-007-1942-2

Air Quality, E. (2019). Existing Legislation - Air Quality Environment -European Commission. Recovered from http://ec.europa.eu/environment/air/quality/legislation/existing_leg.htm

Attard, E (2004). Status of Medicinal and Aromatic Plants in Malta in Baricevic, D., Bernath, J., Maggioni, L. and Lipman E. Report of a Working Group on Medicinal and Aromatic Plants, First Meeting, 12-14 September 2002, Gozd Martuljek, Slovenia, International Plant Genetic Resources Institute, Rome, Italy, 85-87.

Attard, E., \& Bugeja Douglas, A. (2017). Physicochemical Characterization of Maltese Honey. Honey Analysis, Prof. Dr. Vagner Arnaut (Ed.), InTech Recovered from: https://www.intechopen.com/books/ honeyanalysis/physicochemical-characterization-of-maltese-honey

Badiou-Bénéteau, A., Benneveau, A., Géret, F., Delatte, H., Becker, N., Brunet, J., Reynaud, B., \& Belzunces, L. P. (2013). Honeybee biomarkers as promising tools to monitor environmental quality. Environment International, 60, 31-41. doi: 10.1016/j.envint.2013.07.002

Balestra, V., Celli, G., \& Porrini, C. (1992). Bees, honey, larvae and pollen in biomonitoring of atmospheric pollution. Aerobiologia, 8(1), 122-126. doi: $10.1007 / \mathrm{bf} 02291339$

Baranowska, I., Srogi, K., Włochowicz, A., \& Szczepanik, K. (2002). Determination of Heavy Metal Contents in Samples of Medicinal Herbs. Polish Journal of Environmental Studies, 11(5), 467-471. Recovered from http://www.pjoes.com/pdf/11.5/467-471.pdf

Bertholf, L., \& Pilson, J. (1941). Studies on Toxicity to Honeybees of Acid Lead Arsenate, Calcium Arsenate, Phenothiazine, and Cryolite. Journal of Economic Entomology, 34(1), 24-33. doi: 10.1093/jee/34.1.24

Bonvehí, J. S., \& Bermejo, F. O. (2013). Element content of propolis collected from different areas of South Spain. Environmental Monitoring and Assessment, 185(7), 6035-6047.

Borsuk, G., Paleolog, J., Olszewski, K., \& Strachecka, A. (2013). Laboratory assessment of the effect of nanosilver on longevity, sugar syrup ingestion, and infection of honeybees with Nosema spp. Medycyna Weterynaryjna, 69(12), 730-732. Recovered from http://www.medycynawet.edu.pl

Bromenshenk, J., Henderson, C., Wick, C., Stanford, M., Zulich, A., Jabbour, R. E., Deshpande, S. V., McCubbin, P. E., Seccomb, R. A., Welch, P. M. \& Williams, T., (2010). Iridovirus and Microsporidian Linked to Honey Bee Colony Decline. PLOS ONE. doi: 10.1371/journal.pone.0013181
Brown, S., \& Welton, W. (2008). Heavy metal pollution Nova Science Pub Inc; UK.

Çelik, A., Kartal, A., Akdoğan, A., \& Kaska, Y. (2005). Determining the heavy metal pollution in Denizli (Turkey) by using Robinio pseudo-acacia L. Environment International, 31(1), 105-112. doi: 10.1016/j.envint.2004.07.004

Charlesworth, S., Everett, M., McCarthy, R., Ordóñez, A., \& de Miguel, E. (2003). A comparative study of heavy metal concentration and distribution in deposited street dusts in a large and a small urban area: Birmingham and Coventry, West Midlands, UK. Environment International, 29(5), 563-573. doi: 10.1016/s01604120(03)00015-1

Clemens, S., Palmgren, M., \& Krämer, U. (2002). A long way ahead: understanding and engineering plant metal accumulation. Trends in Plant Science, 7(7), 309-315. doi: 10.1016/s13601385(02)02295-1

Conti, M. E., \& Botrè, F. (2001). Honeybees and their products as potential bioindicators of heavy metals contamination. Environmental Monitoring and Assessment, 69(3), 267-282. doi: 10.1023/a:1010719107006

De la Rúa, P., Jaffé, R., Dall'Olio, R., Muñoz, I., \& Serrano, J. (2009). Biodiversity, conservation and current threats to European honeybees. Apidologie, 40(3), 263-284. doi: 10.1051/apido/2009027

Devillers, J., \& Pham-Delègue, M. (2002). Honey bees: Estimating the Environmental Impact of Chemicals. Taylor \& Francis. London, UK.

Di, N., Hladun, K., Zhang, K., Liu, T., \& Trumble, J. (2016). Laboratory bioassays on the impact of cadmium, copper and lead on the development and survival of honeybee (Apis mellifera L.) larvae and foragers. Chemosphere, 152, 530-538. doi: 10.1016/j.chemosphere.2016.03.033

Directive 2001/81/EC of the European Parliament and of the Council of 23 October 2001 on national emission ceilings for certain atmospheric pollutants. Official Journal of the European Communities. L. 309. 2230 .

Directive 2004/107/EC of the European Parliament and of the Council of 15 December 2004 relating to arsenic, cadmium, mercury, nickel and polycyclic aromatic hydrocarbons in ambient air. Official Journal of the European Communities. L. 23. 3-16.

Directive 2008/50/EC of the European Parliament and of the Council of 21 May 2008 on ambient air quality and cleaner air for Europe. Official Journal of the European Communities. L. 152. 1-44.

Dospatliev, L., Kostadinov, K., Mihaylova, G., \& Katrandzhiev, N. (2012). Determination of Heavy Metals (Pb, Zn, Cd and Ni) in Eggplant. Trakia Journal of Sciences, 10(2), 31-35.

ERA (2019). Subsidiary Legislation 549.59 Ambient Air Quality Regulations Recovered from https://eracms.gov.mt/en/Pages/S-L-54959-Ambient-Air-Quality-Regulations.aspx.

Ferreira, B. L., Gonzaga, L. V., Vitali, L., Micke, G. A., Maltez, H. F., Ressureição, C., Oliveira Costa, A. C., \& Fett. R (2019). SouthernBrazilian Geopropolis: A potential source of polyphenolic compounds and assessment of mineral composition. Food Research International, 108683. doi: 10.1016/j.foodres.2019.108683

Finger, D., Kelte Filho, I., Torres, Y. R., \& Quináia, S. P. (2014). Propolis as an indicator of environmental contamination by metals. Bulletin of Environmental Contamination and Toxicology, 92(3), 259-264.

Formicki, G., Gren, A., Stawarz, R., Zysk, B., \& Gal, A. (2013). Metal Content in Honey, Propolis, Wax, and Bee Pollen and Implications for Metal Pollution Monitoring. Polish Journal of Environmental Studies, 22(1) 99-106.

Fowler, D., Skiba, U., Nemitz, E., Choubedar, F., Branford, D., Donovan, R., \& Rowland, P. (2004). Measuring Aerosol and Heavy Metal Deposition on Urban Woodland and Grass Using Inventories of ${ }^{210} \mathrm{~Pb}$ and Metal Concentrations in Soil. Water, Air, \& Soil Pollution: Focus, 4(2/3), 483-499. doi: 10.1023/b:wafo.0000028373.02470.ba

Gagné, F. (2012). A new research journal to understand the interactions of xenobiotics with living organisms. Journal of Xenobiotics, 2(1), 8. doi: 10.4081/xeno.2012.e8

Golomb, D., Ryan, D., Eby, N., Underhill, J., \& Zemba, S. (1997). Atmospheric deposition of toxics onto Massachusetts Bay-I. Metals. Atmospheric Environment, 31(9), 1349-1359. doi: 10.1016/S1352- 


\section{0(96)00276-2}

González-Martín, M., Escuredo, O., Revilla, I., Vivar-Quintana, A., Coello, M., Riocerezo, C., \& Moncada, G. (2015). Determination of the Mineral Composition and Toxic Element Contents of Propolis by Near Infrared Spectroscopy. Sensors, 15(11), 27854-27868. doi: $10.3390 / \mathrm{s} 151127854$

Gutiérrez, M., Molero, R., Gaju, M., Van der Steen, J., Porrini, C., \& Ruiz, J. (2015). Assessment of heavy metal pollution in Córdoba (Spain) by biomonitoring foraging honeybee. Environmental Monitoring and Assessment, 187(10). doi: 10.1007/s10661-015-4877-8

Handika, R. A., Purwaningrum, S. I., \& Lestari, R. A. (2019). Analisis Risiko Non Karsinogenik Pajanan PM10 di Kawasan Komersial, Kota Jambi. Jurnal Serambi Engineering, 4(2). doi: 10.32672/jse.v4i2.1329

Kampouroglou, E., \& Economou-Eliopoulos, M. (2013). Natural contamination by As and heavy metals in soil, their bioaccumulation and potential sources: the case of a travertine limestone quarry, Greece. Open Geosciences, 5(1). doi: 10.2478/s13533-012-0122$\mathrm{y}$

Krmar, M., Radnović, D., \& Frontasyeva, M. V. (2012). Moss Biomonitoring Technique Used to Study Spatial and Temporal Atmospheric Deposition of Heavy Metals and Airborne Radionuclides in Serbia. Essays of Fundamental and Applied Environmental Topics/Ed. DT Mihailovic. Nova Publ. Inc, 159 Ä192.

Leita, L., Muhlbachova, G., Cesco, S., Barbattini, R., \& Mondini, C. (1996). Investigation of the use of honey bees and honey bee products to assess heavy metals contamination. Environmental Monitoring and Assessment, 43(1), 1-9. doi: 10.1007/bf00399566

Lepp, N. W. (Ed.). (2012). Effect of heavy metal pollution on plants: metals in the environment (Vol. 2). Springer Science \& Business Media. London.

Maas, S., Scheifler, R., Benslama, M., Crini, N., Lucot, E., Brahmia, Z., Benyacoub, S. \& Giraudoux, P. (2010). Spatial distribution of heavy metal concentrations in urban, suburban and agricultural soils in a Mediterranean city of Algeria. Environmental Pollution, 158(6), 2294-2301. doi: 10.1016/j.envpol.2010.02.001

Maître, A., Collot-Fertey, D., Anzivino, L. M. M. H. M., Marques, M., Hours, M., \& Stoklov, M. (2003). Municipal waste incinerators: air and biological monitoring of workers for exposure to particles, metals, and organic compounds. Occupational and Environmental Medicine, 60(8), 563-569. doi: 10.1136/oem.60.8.563

Maragou, N., Pavlidis, G., Karasali, H., \& Hatjina, F. (2017). Determination of Arsenic in Honey, Propolis, Pollen and Honey Bees by Microwave Digestion and Hydride Generation Flame Atomic Absorption. Analytical Letters, 50(11), 1831-1838. doi: 10.1080/00032719.2016.1244542

Markle, S. (2013). The case of the vanishing honeybees (1st ed.). Millbrook Press. Minneapolis. USA.

Matin, G., Kargar, N., \& Buyukisik, H. B. (2016). Bio-monitoring of cadmium, lead, arsenic and mercury in industrial districts of Izmir, Turkey by using honey bees, propolis and pine tree leaves. Ecological Engineering, 90, 331-335. doi: 10.1016/j.ecoleng.2016.01.035.

Nikolić, T. V., Kojić, D., Orčić, S., Batinić, D., Vukašinović, E., Blagojević, D. P., \& Purać, J. (2016). The impact of sublethal concentrations of $\mathrm{Cu}$, $\mathrm{Pb}$ and $\mathrm{Cd}$ on honey bee redox status, superoxide dismutase and catalase in laboratory conditions. Chemosphere, 164, 98-105. doi: 10.1016/j.chemosphere.2016.08.077.

Onder, S., \& Dursun, S. (2006). Air borne heavy metal pollution of Cedrus libani (A. Rich.) in the city centre of Konya (Turkey). Atmospheric Environment, 40(6), 1122-1133. doi: 10.1016/j.atmosenv.2005.11.006

Ordonez, A., Loredo, J., De Miguel, E., \& Charlesworth, S. (2003). Distribution of Heavy Metals in the Street Dusts and Soils of an Industrial City in Northern Spain. Archives of Environmental Contamination and Toxicology, 44(2), 160-170. doi: 10.1007/s00244002-2005-6

Peris, M., Micó, C., Recatalá, L., Sánchez, R., \& Sánchez, J. (2007). Heavy metal contents in horticultural crops of a representative area of the European Mediterranean region. Science of the Total Environment, 378(1-2), 42-48. doi: 10.1016/j.scitotenv.2007.01.030

Perugini, M., Manera, M., Grotta, L., Abete, M., Tarasco, R., \& Amorena, M. (2010). Heavy Metal $(\mathrm{Hg}, \mathrm{Cr}, \mathrm{Cd}$, and $\mathrm{Pb}$ ) Contamination in Urban Areas and Wildlife Reserves: Honeybees as Bioindicators. Biological
Trace Element Research, 140(2), 170-176. doi: 10.1007/s12011010-8688-Z

Popescu, I. V., Frontasyeva, M., Stihi, C., Cimpoca, G. V., Radulescu, C., Gheboianu, A., Oros, C., Vlaicu, G., Petre, C., Bancuta, I., \& Dulama, I. D. (2010). Nuclear and nuclear related analytical methods applied in environmental research. Romanian Journal of Physics. 55(7-8), 821829.

Porrini, C., Sabatini, A. G., Girotti, S., Ghini, S., Medrzycki, P., Grillenzoni, F., Bortolotti, L., Gattavecchia, E., \& Celli, G. (2003). Honey bees and bee products as monitors of the environmental contamination. Apiacta, 38(1), 63-70.

Roman, A. (2010). Levels of Copper, Selenium, Lead, and Cadmium in Forager Bees. Polish Journal of Environmental Studies, 19(3) 663-669.

Roman, A., Madras-Majewska, B., \& Popiela-Pleban, E. (2011). Comparative study of selected toxic elements in propolis and honey. Journal of Apicultural Science, 55(2), 97-106.z

Sabin, L. D., Lim, J. H., Stolzenbach, K. D., \& Schiff, K. C. (2006). Atmospheric dry deposition of trace metals in the coastal region of Los Angeles, California, USA. Environmental Toxicology and Chemistry: An International Journal, 25(9), 2334-2341. doi: 10.1897/05-300R.1

Sakata, M., \& Marumoto, K. (2004). Dry deposition fluxes and deposition velocities of trace metals in the Tokyo metropolitan area measured with a water surface sampler. Environmental Science \& Technology, 38(7), 2190-2197. doi: 10.1021/es030467k

Satta, A., Verdinelli, M., Ruiu, L., Buffa, F., Salis, S., Sassu, A., \& Floris, I. (2012). Combination of beehive matrices analysis and ant biodiversity to study heavy metal pollution impact in a post-mining area (Sardinia, Italy). Environmental Science and Pollution Research, 19(9), 3977-3988. doi. 10.1007/s11356-012-0921-1

Schembri, P. J. (1997). The Maltese Islands: climate, vegetation and landscape. GeoJournal, 41(2), 1-11. doi: 10.1023/a:1006828706452

Schreuder, M. D., Brewer, C. A., \& Heine, C. (2001). Modelled influences of non-exchanging trichomes on leaf boundary layers and gas exchange. Journal of Theoretical Biology, 210(1), 23-32.

Sheppard, W., Arias, M., Grech, A., \& Meixner, M. (1997). Apis mellifera ruttneri, a new honey bee subspecies from Malta. Apidologie, 28(5), 287-293. doi: 10.1051/apido:19970505

Sultana, J. \& Falzon, V. (2002). Wildlife of the Maltese Islands (1st ed.). BirdLife Malta. Floriana, Malta.

Suryanarayanan, S., \& Kleinman, D. (2016). Vanishing bees: Science, Politics, and Honeybee Health (Nature, Society, and Culture) (1st ed.). Rutgers University Press. New Jersey, USA.

Swaileh, K., \& Abdulkhaliq, A. (2013). Analysis of aflatoxins, caffeine, nicotine and heavy metals in Palestinian multifloral honey from different geographic regions. Journal of the Science of Food and Agriculture, 93(9), 2116-2120. doi: 10.1002/jsfa.6014

Tautz, J., Sandeman, D., \& Heilmann, H. (2008). The buzz about bees: Biology of a Superorganism ( $1^{\text {st }}$ ed.). Springer. Berlin, Germany.

Tchounwou, P., Yedjou, C., Patlolla, A., \& Sutton, D. (2012). Heavy Metal Toxicity and the Environment. Experientia Supplementum, 133-164. doi: 10.1007/978-3-7643-8340-46

Van der Steen, J. (2016). Beehold: the colony of the honeybee (Apis mellifera L) as a bio-sampler for pollutants and plant pathogens (Ph.D. thesis) Wageningen University. Netherlands.

Van der Steen, J., Cornelissen, B., Blacquière, T., Pijnenburg, J., \& Severijnen, M. (2016). Think regionally, act locally: metals in honeybee workers in the Netherlands (surveillance study 2008). Environmental Monitoring and Assessment, 188(8). doi: 10.1007/s10661-016-5451-8

Van der Steen, J., de Kraker, J., \& Grotenhuis, J. T. C. (2015). Assessment of the potential of honeybees (Apis mellifera L.) in biomonitoring of air pollution by cadmium, lead and vanadium. Journal of Environmental Protection, 6(2), 96-102. doi: 10.4236/jep.2015.62011.

Van der Steen, J., de Kraker, J., \& Grotenhuis, T. (2011). Spatial and temporal variation of metal concentrations in adult honeybees (Apis mellifera L.). Environmental Monitoring and Assessment, 184(7), 4119-4126. doi: 10.1007/s10661-011-2248-7

Vernet, J. (1992). Impact of heavy metals on the environment (Volume 2). Elsevier. Amsterdam, The Netherlands. 
Wunderground.com (2017) Weather History for Luqa, Mauritania Weather Underground. Recovered from https://www.wunderground.com/history/

Wilson-Rich, N., Allin, K., Carreck, N., \& Quigley, A. (2014). The Bee: A Natural History (1st ed.). Princeton University Press. New Jersey, USA.

Xian, Y., Wang, M., \& Chen, W. (2015). Quantitative assessment on soil enzyme activities of heavy metal contaminated soils with various soil properties. Chemosphere, 139, 604-608. doi: 10.1016/j.chemosphere.2014.12.060

Zhelyazkova, I., Atanasova, S., Barakova, V., \& Mihaylova, G. (2010). Content of heavy metals and metalloids in bees and bee products from areas with different degree of anthropogenic impact. Agricultural Science and Technology, 3(1), 136 - 142.

\section{License: Creative Commons CC BY 4.0}

This article was published with open access for distribution under the terms of the Creative Commons Attribution License, which allows unrestricted use, distribution, and reproduction in any medium, provided the original work is properly cited. 